\title{
The Relationship Between Vitamin D Gene Polymorphisms and the Diagnosis of Prostate Cancer in Patients with High Prostate-Specific Antigen Value
}

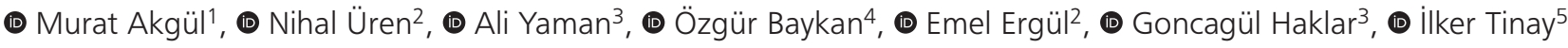 \\ ${ }^{1}$ Tekirdağ Namık Kemal University Faculty of Medicine, Department of Urology, Tekirdağ, Turkey \\ ${ }^{2}$ Kocaeli University Faculty of Medicine, Department of Medical Biology and Genetics, Kocaeli, Turkey \\ ${ }^{3}$ Marmara University Faculty of Medicine, Department of Biochemistry, Istanbul, Turkey \\ ${ }^{4}$ Balıkesir University Faculty of Medicine, Department of Biochemistry, Balıkesir, Turkey \\ ${ }^{5}$ Marmara University Faculty of Medicine, Department of Urology, Istanbul, Turkey
}

\begin{abstract}
Objective: To investigate the effects of vitamin D levels and vitamin D receptor (VDR) Bsml, Fokl, Taql, and Apal gene polymorphisms on prostate cancer (PCa) diagnosis in Turkish men with high prostate-specific antigen (PSA) levels during screening.

Materials and Methods: Patients who were admitted to the outpatient clinic with elevated PSA levels and were scheduled for transrectal prostate biopsy were included. Patients diagnosed with PCa were divided into two groups of either localized disease (low/intermediate/high risk) or metastatic disease for subgroup analysis. The control group comprised patients whose biopsies revealed benign pathologies. Blood samples were collected from each patient after 12 hours of fasting before the prostate biopsy. Vitamin D levels and VDR gene polymorphisms were determined by ECLIA method and restriction fragment length polymorphism analysis, respectively.

Results: A total of 77 patients (PCa, 39; benign, 38) were included in the study. The frequencies of Bsml, Fokl, Taql, and Apal genotypes for PCa and benign groups were evaluated. Vitamin D deficiency was detected in $88.6 \%$ and $94.9 \%$ of the benign and PCa groups, respectively ( $p=0.176)$. The Fokl Ff and Bsml bb genotypes, and Fokl FF and Bsml Bb genotypes were found to be more common in the PCa and benign groups, respectively. Apal Aa and Taql Tt were found to be more frequent in both groups. In patients with metastatic PCa; Bsml Bb genotype, Apal Aa genotype, and Taql Tt genotypes were found to be more common. Conclusion: Although Bsml Bb genotype, Apal Aa genotype, and Taql Tt genotypes were more commonly found in patients with metastatic PCa, further studies with increased sample sizes are needed to support this relationship in the Turkish PCa population.
\end{abstract}

Keywords: Prostate cancer, vitamin D, gene polymorphism

\section{Introduction}

Globally, prostate cancer ( $\mathrm{PCa}$ ) is the $2^{\text {nd }}$ most common cancer (13\%) and $5^{\text {th }}$ most common lethal malignancy $(6.7 \%)$ in men per the GLOBOCAN data (1). Its etiology is multifactorial and includes factors like age, ethnicity, family history, environment, and genetic predisposition. Epidemiological evidence has suggested that low exposure to sunlight and vitamin D (vitD) deficiency may be one of the risk factors for PCa mortality (2). The active form of vitD inhibits the proliferation of human PCa cell lines in experimental studies (3). The anti-proliferative effect of
vitD is regulated through a pathway involving vitamin $D$ receptor (VDR), a member of the nuclear steroid hormone receptor family (4). The VDR gene is located on chromosome 12q12-q14. Some of the single-nucleotide polymorphisms (SNPs) of VDR gene are believed to be related with PCa. The most frequently studied SNPs are rs1544410 (Bsml), rs2228570 (Fokl), rs731236 (Taql), and rs7975232 (Apal) polymorphisms (5).

Our aim was to investigate the effects of vitD levels and VDR gene polymorphisms (Bsml, Fokl, Taql, and Apal) on PCa diagnosis in Turkish men with high prostate-specific antigen (PSA) levels during screening.

Cite this article as: Akgül M, Üren N, Yaman A, Baykan Ö, Ergül E, Haklar G, Tinay i. The Relationship Between Vitamin D Gene Polymorphisms and the Diagnosis of Prostate Cancer in Patients with High Prostate-Specific Antigen Value. Bull Urooncol 2020;19(4):191-195

Address for Correspondence: Murat Akgül, Tekirdağ Namık Kemal University Faculty of Medicine, Department of Urology, Tekirdağ, Turkey Phone: +90 5053399602 E-mail: drmuratakgul@gmail.com ORCID-ID: orcid.org/0000-0001-6187-1940 Received: 20.12.2019 Accepted: 18.01.2020 


\section{Materials and Methods}

Blood samples of 77 patients who reported to our outpatient clinic with high PSA levels were examined. Only those patients who did not have a previous history of cancer were included. Additionally, the study was conducted during the winter months to avoid the fluctuations in vitD levels. PCa diagnosis was made by ultrasound guided multifocal prostate biopsy that is considered as the gold standard. Patients diagnosed with PCa were further grouped into those with localized disease (low/intermediate/ high risk) or metastatic disease for subgroup analysis (6); while those without PCa comprised the benign group.

The collected blood samples were centrifuged at 1,300 $\times \mathrm{g}$ for 10 minutes and kept at $-20{ }^{\circ} \mathrm{C}$ to be analyzed for $25(\mathrm{OH})$ $D$ levels that were determined using an HPLC method (Thermo Finnigan, Germany) and commercially produced 25(OH)D extraction kit, calibrator, and control sera (Zivak Technologies, Turkey). Average intra- and inter-assay coefficients of variation for the indicated reference ranges of $25(\mathrm{OH}) \mathrm{D}_{2}(24.6-80.7 \mathrm{ng} /$ $\mathrm{mL}$ ) and $25(\mathrm{OH}) \mathrm{D}_{3}(21.5-75.5 \mathrm{ng} / \mathrm{mL})$ were below $5 \%$, and both $25(\mathrm{OH}) \mathrm{D}_{2}$ and $25(\mathrm{OH}) \mathrm{D}_{3}$ demonstrated linear correlation up to $200 \mathrm{ng} / \mathrm{mL}$.

Polymorphisms were analyzed by collecting $6 \mathrm{~mL}$ whole blood samples into EDTA containing tubes (Becton Dickinson, USA) and stored at $-20{ }^{\circ} \mathrm{C}$ until the DNA isolation procedure was performed.

DNA isolation was performed using a salt (ammonium acetate) precipitation method (7), while for the determination of SNPS gene, polymerase chain reaction (PCR)-restriction fragment length polymorphism method was used.

The PCR was performed using a thermal cycler (Eppendorf Mastercycler, USA) (Table 1) $(8,9)$. PCR products were digested with Apal, Fokl, Bsml (Thermo- Scientific, USA), and Taql (Fermantes, Lithuania) restriction enzymes. The digested products were analyzed on polyacrylamide gel (Vertical electrophoresis systems, Bio-Rad, USA) followed by silver staining (Carlo Erba, Italy).

The study has been approved by the Marmara University Clinical Research Ethics Committee (the protocol number: 09.2013.0157) and conducted in conformity with the Declaration of Helsinki in 1995. Written informed consent were obtained from all patients included in the study. In addition the study was supported by Marmara Universtity Scientific Research Projects Committee with the project number: SAG-B-041213-0442.

\section{Statistical Analysis}

Data was analysed using SPSS 17.0 and MedCalc 12.3.0 programs. Visual graphs (histograms etc) and appropriate statistical tests (Kolmogorov-Smirnov and Shapiro-Wilk) were used for the evaluation of the normality of data. Student's t-test or Mann-Whitney $U$ test was used for the comparison of mean values of 2 independent groups.

\section{Results}

A total of 77 patients with high PSA levels (benign, 38; PCa, 39) were included in the study. Among the PCa subgroups, there were $10(13 \%)$ and 29 patients with metastatic and localized disease, respectively. In the latter; 9 (11.7\%), 13 (16.9\%), and 7 (9.1\%) patients had low, intermediate, and high risk, respectively. Treatment modalities for non-metastatic $\mathrm{PCa}$ included radical prostatectomy (RP) in $12(41.4 \%)$, active surveillance (AS) in 8 (27.6\%), and radiotherapy (RT) in 8 (27.6\%) patients. Biochemical PSA recurrence after definitive treatment (RP and RT) was observed in 5 (20\%) patients.

The demographic data for the PCa and benign groups, including age, smoking status, and body mass index (BMI) are shown in Table 2. VitD and PSA values are shown in Table 3.

There was no statistically significant difference between the two groups in terms of age, smoking status, and BMI. The vitD levels were higher in the benign than in the PCa group $(p=0.176)$.

Patients with VitD levels below $20 \mathrm{ng} / \mathrm{mL}$ were diagnosed with vitD deficiency that was detected in $88.6 \%$ and $94.9 \%$ of the patients in benign and PCa groups, respectively. Conversely, PSA values of benign and PCa groups were significantly different due to the contribution of the high PSA values of the metastatic PCa patients $(p=0.002)$.

\begin{tabular}{|c|c|c|}
\hline SNPs & Primers (F: forward; R: reverse) & PCR conditions \\
\hline $\begin{array}{l}\text { rs7975232 } \\
\text { (Apal) }\end{array}$ & $\begin{array}{l}\text { F: 5'-CAG AGC ATG GAC AGG GAG CAA-3' } \\
\text { R: 5'-GCA ACT CCT CAT GGC TGA GGT CTC-3' }\end{array}$ & $\begin{array}{l}94^{\circ} \mathrm{C} / 5 \text { minutes } \\
\left(94^{\circ} \mathrm{C} / 1 \text { minute } 65^{\circ} \mathrm{C} / 1 \text { minute }-72^{\circ} \mathrm{C} / 1 \text { minute for } 30 \text { cycles }\right) \\
72^{\circ} \mathrm{C} / 7 \text { minutes }\end{array}$ \\
\hline $\begin{array}{l}\text { rs1544410 } \\
\text { (Bsml) }\end{array}$ & $\begin{array}{l}\text { F: 5'-GGG AGA CGT AGC AAA AGG-3' } \\
\text { R: 5'-AGA GGT CAA GGG TCA CTG-3' }\end{array}$ & $\begin{array}{l}94^{\circ} \mathrm{C} / 3 \text { minutes } \\
\left(94^{\circ} \mathrm{C} / 1 \text { minute } 54^{\circ} \mathrm{C} / 1 \text { minute }-72{ }^{\circ} \mathrm{C} / 1 \text { minute for } 30 \text { cycles) }\right. \\
72{ }^{\circ} \mathrm{C} / 7 \text { minutes }\end{array}$ \\
\hline $\begin{array}{l}\text { rs2228570 } \\
\text { (Fokl) }\end{array}$ & $\begin{array}{l}\text { F: 5'-GAT GCC AGC TGG CCC TGG CAC TG-3' } \\
\text { R: 5'-ATG GAA ACA CCT TGC TTC TTC TCC CTC-3' }\end{array}$ & $\begin{array}{l}94^{\circ} \mathrm{C} / 3 \text { minutes } \\
\left(94^{\circ} \mathrm{C} / 1 \text { minute } 60^{\circ} \mathrm{C} / 1 \text { minute }-72^{\circ} \mathrm{C} / 1 \text { minute for } 30 \text { cycles) }\right. \\
72^{\circ} \mathrm{C} / 7 \text { minutes }\end{array}$ \\
\hline $\begin{array}{l}\text { rs731236 } \\
\text { (Taql) }\end{array}$ & $\begin{array}{l}\text { F: 5'-CAG AGC ATG GAC AGG GAG CAA-3' } \\
\text { R: 5'-GCA ACT CCT CAT GGC TGA GGT CTC-3' }\end{array}$ & $\begin{array}{l}94^{\circ} \mathrm{C} / 5 \text { minutes } \\
\left(94^{\circ} \mathrm{C} / 1 \text { minute } 65^{\circ} \mathrm{C} / 1 \text { minute }-72^{\circ} \mathrm{C} / 1 \text { minute for } 30 \text { cycles) }\right. \\
72^{\circ} \mathrm{C} / 7 \text { minutes }\end{array}$ \\
\hline
\end{tabular}


The frequencies of Bsml, Fokl, Taql, and Apal genotypes in benign and PCa groups are presented in Table 4. The Fokl Ff and Bsml bb genotypes, and the Fokl FF and Bsml Bb genotypes were more common in $\mathrm{PCa}$ and benign groups, respectively. Apal Aa and Taql Tt were found with similar frequencies in both groups. However, the results were not statistically significant.

On subgroup analysis of patients diagnosed with PCa there were no significant differences $(p=0.436)$. In patients with metastatic disease; Bsml Bb genotype, Apal Aa genotype, and Taql Tt genotypes were found to be more common. Conversely, Bsml bb genotype, Fok Ff genotype, Apal aa genotype, and Taql TT genotypes were found to be more common in patients with low risk PCa group who were candidates for AS.

Table 2. The demographic data for the benign and prostate cancer groups

\begin{tabular}{|l|l|l|l|}
\hline & $\begin{array}{l}\text { Benign } \\
(\mathbf{n}=38)\end{array}$ & $\begin{array}{l}\text { PCa } \\
(\mathbf{n}=39)\end{array}$ & p-value \\
\hline Age (year) & $69.6 \pm 2.64$ & $69.2 \pm 5.9$ & $\mathrm{p}=0.96^{*}$ \\
\hline Smoking status (\%) & 52.6 & 64.1 & $\mathrm{p}=0.307^{* *}$ \\
\hline Body mass index (kg/m²) & $26.9 \pm 2.85$ & $27.07 \pm 3.39$ & $\mathrm{p}=0.82^{*}$ \\
\hline *Student t-test, **chi-square test, PCa: Prostate cancer \\
\hline
\end{tabular}

Table 3. Vitamin D and PSA values of the groups

\begin{tabular}{|l|l|l|l|}
\hline & $\begin{array}{l}\text { Benign } \\
(\mathbf{n}=38)\end{array}$ & $\begin{array}{l}\text { PCa } \\
(\mathbf{n}=39)\end{array}$ & $p$-value \\
\hline vitD $(\mathrm{ng} / \mathrm{mL})$ & $12.04 \pm 4.15$ & $10.3 \pm 5.91$ & $\mathrm{p}=0.176^{*}$ \\
\hline PSA $(\mathrm{ng} / \mathrm{dL})$ & $6.76 \pm 4.35$ & $33.01 \pm 48.6$ & $\mathrm{p}=0.002^{*}$ \\
\hline
\end{tabular}

*Student t-test, PSA: Prostate-specific antigen, PCa: Prostate cancer, vitD: Vitamin D

Table 4. The frequencies of Bsml, Fokl, Taql, and Apal genotype for benign and prostat cancer groups

\begin{tabular}{|c|c|c|c|c|}
\hline & & Benign (\%) & PCa (\%) & $p$-value \\
\hline \multirow{3}{*}{ Apal } & aa & 21.2 & 28.9 & \multirow{3}{*}{0.747} \\
\hline & $\mathrm{Aa}$ & 45.5 & 39.5 & \\
\hline & AA & 33.3 & 31.6 & \\
\hline \multirow{3}{*}{ Fokl } & ff & 7.9 & 12.8 & \multirow{3}{*}{0.43} \\
\hline & Ff & 42.1 & 51.3 & \\
\hline & $\mathrm{FF}$ & 50 & 35.9 & \\
\hline \multirow{3}{*}{ Taql } & tt & 15.2 & 7.9 & \multirow{3}{*}{0.567} \\
\hline & Tt & 48.5 & 47.4 & \\
\hline & TT & 36.4 & 44.7 & \\
\hline \multirow{3}{*}{ Bsml } & bb & 35.1 & 53.8 & \multirow{3}{*}{0.17} \\
\hline & $\mathrm{Bb}$ & 45.9 & 38.5 & \\
\hline & BB & 18.9 & 7.7 & \\
\hline
\end{tabular}

\section{Discussion}

VitD could be defined as a hormone rather than a vitamin because of the complexity and diversity of its production. It is not categorized as an essential vitamin and can be synthesized by the help of ultraviolet-B rays. VDR protein is an intracellular receptor of vitD that is coded by the VDR gene. VitD affects the expression of targeted $V D R$ genes through these special receptors (10). It is believed to have a role in cancer pathogenesis, especially in decreasing the proliferation, invasion, angiogenesis, metastatic spread, and cellular differentiation. However its deficiency is a major public health problem across all age groups, worldwide. In our study, both PCa and benign groups were deficient in vitD, with lower levels observed in PCa than in the benign group. PCa risk has been shown to be inversely associated with vitD concentration (11). However, large-sized prospective randomized studies are required to clarify the relationship between vitD and PCa (12).

Previous studies demonstrated that VDR gene polymorphisms that include; Fokl, Bsml, Apal, Taql, and Cdx2; are associated with many organ cancers including that of the urinary system $(13,14,15)$. Onen et al. (16) evaluated vitD polymorphism for PCa only at Apal, Taql, and Bsml genes in the Turkish population. Similar to our findings they found that Apal Aa, Taql Tt, and $\mathrm{Bsml} \mathrm{Bb}$ alles were the dominant genotypes in benign groups. Additionally, Apal Aa alles were the dominant genotype in PCa patients. The ratio of other alleles and their distribution in benign and PCa groups were also similar. Fokl polymorphism is also considered as a potential biomarker for PCa risk identification in Caucasians (17). In our study, the Fokl Ff and Fokl FF genotypes were found to be more frequent in PCa and benign groups, respectively.

Although, there are many studies regarding the relationship between PCa and VDR gene polymorphisms, few have compared this according to the metastatic status or risk classification of PCa. Since PCa treatment modalities vary among patients, additional guidelines are needed; especially in the low-risk groups. For patients with low-risk PCa, AS without curative treatment is a possible treatment option (6). Therefore, it is particularly important to distinguish between low-risk groups and highly aggressive metastatic groups. In our study, we evaluated our results based on the distinction between the different risk groups and metastatic disease groups.

VDR gene polymorphisms differ among ethnic populations as the alleles of metabolic genes are not equally distributed (18). PCa is also affected by genetic differences; its incidence and mortality rates are highest in Australia, Europe, and North America and lowest in Asia, especially South-Central Asian ethnic populations (1). The observed association between the VDR polymorphism and PCa risk may be substantially different among populations. However, most of the meta-analyses indicated that there is no significant association between different populations and VDR genotypes and PCa risk. This may be because of the ethnic variations in genotypes, genotyping techniques, or the limited sample size that may not have enough statistical power $(19,20,21)$.

Although, it has been demonstrated that vitD inhibits the growth of cells obtained from benign prostatic hyperplasia (BPH) tissue, few studies have reported that VDR polymorphisms are related to the risk of $\mathrm{BPH}$ (22). It is impossible to exclude $\mathrm{BPH}$ patients from the control group with their high PSA values. Although, few studies have claimed that they excluded patients with $\mathrm{BPH}$, 
this may not be entirely true. While, most of the studies included BPH patients in their control group, we did not consider the presence or absence of BPH in our control group. Therefore, our comparisons were limited, and this may have led to a potential bias.

\section{Study Limitations}

In our study, blood samples were drawn from 158 patients who reported to our outpatient clinic with high PSA levels; however the polymorphism results of only 77 patients could be obtained due to cold chain failure. Therefore, we were able to analyze only half of our sample. Furthermore, we analyzed patients from the Marmara local region in Turkey to ensure genetic homogeneity. However, this region comprises the highest number of immigrants, and this could have interfered with our intended objective. Lastly, we evaluated the vitD levels during the winter season to avoid seasonal fluctuations. However, the sun exposure was the lowest at this time and that may have affected the vitD levels adversely. We were also not aware of the duration of the vitD deficiency in our patients.

\section{Conclusion}

Although, the Bsml Bb, Apal Aa, and Taql Tt genotypes were more commonly found in patients with metastatic $\mathrm{PCa}$; the Fokl $\mathrm{Ff}$ and $\mathrm{Bsml}$ bb genotypes were more commonly found across all PCa risk groups. Large-sized, well-designed epidemiologic studies that evaluate the different risk groups and metastatic PCa groups may help to highlight the complex interactions between vitD, VDR gene polymorphisms, and PCa.

\section{Acknowledgements}

Publication: The results of the study were not published in full or in part in form of abstracts.

Contribution: There is not any contributors who may not be listed as authors.

Conflict of Interest: No conflict of interest was declared by the authors.

Financial Disclosure: This investigation was supported by Marmara University Scientific Research Projects Committee with project number SAG-B-04213-0442.

\section{Ethics}

Ethics Committee Approval: The study has been approved by the Marmara University Clinical Research Ethics Committee (the protocol number: 09.2013 .0157$)$ and conducted in conformity with the Declaration of Helsinki in 1995.

Informed Consent: Written informed consent were obtained from all patients included in the study.

Peer-review: Externally and internally peer-reviewed.

\section{Authorship Contributions}

Concept: M.A., N.Ü., Ö.B., Design: M.A., Data Collection or Processing: M.A., N.Ü., A.Y., Analysis or Interpretation: E.E., G.H., I.T., Literature Search: I.T., Writing: M.A., I.T.

\section{References}

1. Bray F, Ferlay J, Soerjomataram I, et al. Global cancer statistics 2018: GLOBOCAN estimates of incidence and mortality worldwide for 36 cancers in 185 countries. Can J Clinic 2018;68:394-424.

2. Schwartz GG, Hulka BS. Is vitamin D deficiency a risk factor for prostate cancer? (Hypothesis) Anticancer Res 1990;10:1307-1311.

3. Miller GJ, Stapleton GE, Hedlund TE, et al. Vitamin D receptor expression, 24-hydroxylase activity, and inhibition of growth by 1 alpha, 25-dihydroxyvitamin D3 in seven human prostatic carcinoma cell lines. Clin Cancer Res 1995;1:997-1003.

4. Hedlund TE, Moffatt KA, Miller G). Vitamin D receptor expression is required for growth modulation by 1 alpha,25-dihydroxyvitamin D3 in the human prostatic carcinoma cell line ALVA-31. J Steroid Biochem Mol Biol 1996;58:277-288.

5. Cheteri MBK, Stanford JL, Friedrichsen DM, et al. Vitamin D receptor gene polymorphisms and prostate cancer risk. The Prostate 2004;59:409-418.

6. Mottet N, van den Bergh RCN, Briers E, et al. EAU - EANM - ESTRO ESUR - SIOG Guidelines on Prostate Cancer. European Association of Urology 2019. https://uroweb.org/wp-content/uploads/EAU-ESURESTRO-SIOG-Guidelines-on-Prostate-Cancer-large-text-V2.pdf

7. Miller SA, Dykes DD, Polesky HF. A simple salting out proce- dure for extracting DNA from human nucleated cells. Nucleic Acids Res 1988; 16:1215.

8. Yaylım-Eraltan I, Arzu Ergen $\mathrm{H}$, Arikan $\mathrm{S}$, et al. Investigation of the VDR gene polymorphisms association with susceptibility to colorectal cancer. Cell Biochem Funct 2007; 25:731-737.

9. Mitra S, Desai M, Ikram Khatkhatay M. Vitamin D receptor gene polymorphisms and bone mineral density in postmenopausal Indian women. Maturitas 2006;55:27-35.

10. Klemm KM, Klien MJ. Biochemical Markers of Bone Metabolism. In: McPherson RA, Pincus MR, Eds. Henry's Clinical Diagnosis and Management. Louis, MO: Elsevier: 2017. p. 193-209.

11. Deschasaux $M$, Souberbielle JC, Latino-Martel $P$, et al. A prospective study of plasma 25-hydroxyvitamin D concentration and prostate cancer risk. Br J Nutr 2016;115:305-314.

12. Christakos S, Li S, De La Cruz J, et al. New developments in our understanding of vitamin metabolism, action and treatment. Metabolism 2019;98:112-120.

13. Xie WJ, Lin ZJ, Zhang XL, et al. Relationship between Vitamin D receptor gene polymorphism and renal cell carcinoma susceptibility. J Cancer Res Ther 2018;14:820.

14. Baykan O, Akgul M, Uren N, et al. The Relationship Between Urothelial Type Bladder Cancer, Plasma 25-Hydroxyvitamin D Levels, and Vitamin D Receptor Apal Bsml Fokl, and Taql Polymorphisms. Clin Lab 2019;65.

15. Tagliabue E, Raimondi S, Gandini S. Meta-analysis of vitamin Dbinding protein and cancer risk. Cancer Epidemiol Biomarkers Prev 2015;24:1758-1765.

16. Onen IH, Ekmekci A, Eroglu $M$, et al. Association of genetic polymorphisms in vitamin D receptor gene and susceptibility to sporadic prostate cancer. Exp Biol Med 2008;233:1608-1614.

17. Kang S, Zhao Y, Liu J, et al. Association of Vitamin D receptor Fok I polymorphism with the risk of prostate cancer: a meta-analysis. Oncotarget 2016;7:77878-77889.

18. Nejentsev S, Godfrey L, Snook H, et al. Comparative high- resolution analysis of linkage disequilibrium and tag single nucleotide polymorphisms between populations in the vitamin $\mathrm{D}$ receptor gene. Hum Mol Genet 2004;13:1633-1639.

19. Guo Z, Wen J, Kan Q, et al. Lack of association between vitamin D receptor gene Fokl and Bsml polymorphisms and prostate cancer risk: an updated meta-analysis involving 21,756 subjects. Tumor Biology 2013;34:3189-3200. 
20. Wang K, Wu G, Li J, et al. Role of vitamin D receptor gene Cdx2 and Apa1 polymorphisms in prostate cancer susceptibility: a metaanalysis. BMC Cancer 2016;16:674.

21. Kang $S$, Zhao $Y$, Wang $L$, et al. Lack of association between the risk of prostate cancer and vitamin D receptor Bsm I polymorphism: a meta-analysis of 27 published studies. Cancer Manag Res 2018;10:2377-2387.

22. Peehl DM, Skowronski RJ, Leung GK, et al. Antiproliferative effects of 1,25-dihydroxyvitamin D3 on primary cultures of human prostatic cells. Cancer Res 1994;54:805-810. 